\title{
THE SAYINGS OF ROBERT HUTCHISON
}

\author{
BY
}

DONALD HUNTER

'I swear by Apollo and Aesculapius to reckon him who taught me this Art equally dear to me as my parents'

All who are privileged to know Sir Robert Hutchison must remember with pleasure many of his sayings. Thousands more who have never met him can revel in the dry humour of his writings. Thus in the Harveian Oration he wrote of Harvey that ' a sense of humour must have been of value to him ... nor need we have any doubt that Harvey was always able to recognize in himself what W. K. Clifford called the still small voice that whispers " fiddlesticks"',

In his address on Fashions and Fads in Medicine he wrote:

'Workers in V.D. clinics soon come to see everything through what Dr. Gee called "a syphilitic fog." As Oliver Wendell Holmes said of the great French syphilographer Ricord, they would submit Diana to treatment with mineral specifics, and order a course of blue pills for the Vestal Virgins.'

And then there are sentences in his famous lecture on diagnosis which rank among the gems of medical writing:

'Judgement seems to be an inborn faculty, the result of a union of mind and character, which a man either has or has not, and it is almost as difficult for him to increase it as to add a cubit to his stature.'

'It is quite impossible that you should always be right in your diagnosis, if only for the reason that disease does not always play the game. It is better, however, to be wrong on sound principles than right by chance. Guessing is to be avoided at all costs; for if you once get into the habit of guessing you are diagnostically damned.'

The following is a collection of some of his sayings both at the bedside and in the lecture room. No doubt, as time has passed, some of these have been embellished with fictitious additions, but that is only to be expected.

Addressing the London Hospital Medical Society he explained what a great feat it was for him, as an Edinburgh man, to have been appointed to the staff of the London Hospital. In those days hospitals appointed only men they had trained themselves. Indeed had Hippocrates applied for Bart's he would have been turned down: "We can't have anything to do with an outsider. You're not from Bart's, you're from Kos.'

When a new clerk percussed a child's chest he would say: 'My boy, you have joined the band of people who leave behind them a trail of broken ribs.' Sometimes, if a man percussed too hard he would reprimand him. 'But I got resonance, sir.' 'Yes, but that was the resonance of the ward below.' If a clerk attempted to percuss the lung too low down at the back he would say, 'I was not aware the kidney was an organ which lent itself to percussion.'

Sometimes at Great Ormond Street he referred to his clerks as 'A curious collection of crapulous cretins creeping from crib to crib.' At the London he was content to call them ' tabetic snails.'

Alan Perry says he remembers Robert Hutchison beginning a lecture on dietetics: 'Gentlemen, you may know a vegetarian because he is full of two things-wind and self-righteousness.'

Kenneth Tallerman remembers him giving an address on the history of pediatrics: 'Gentlemen, after the anti-natalists have allowed a woman to conceive . . . then the antenatalists get busy.'

Sir Horace Evans remembers that he used to say: ' Rheumatic fever is a disease which is commoner in what some ironical humorist has called the working class.'

Dick Bomford says that when Bobby Hutch delivered the Schorstein Lecture his opening sentence ran: 'Like many but by no means all of his race Gustave Isidore Schorstein was a man of great personal charm.'

As a student Willie M. Morris was one day in the medical out-patient department at the London when Robert was presiding. A fat Cockney woman brought in a dirty, thin, active baby, who succeeded in drowning the conversation, and threw all the toys to the floor. He then made an attempt on Robert's gold watch. Noticing that the baby had a mark down one cheek from a discharging ear, Robert seized upon the opportunity to reach for a transfer card, and wrote on it:

\footnotetext{
'Otorrhoea: to aural department.'

'Mother, your baby has a discharging ear. Take it to the ear specialist.'

'Oh, doctor, he's attending there these last five weeks.'

Giving up the unequal struggle Robert turned to his class:

- Gentlemen, I have recently contracted matrimony. If Providence sees fit to bestow on me
} 
progeny and that progeny be of the male sex, I shall one day have to consider his future. If he be a brilliant lad far above normal, I shall make of him a physician. If he be merely normal, I shall make of him a surgeon. If he be slightly subnormal I shall make of him a gynaecologist, but, gentlemen, if he be absolutely mentally defective, I shall make of him an ear, nose and throat surgeon.'

Charles Donald says that in difficult cases of infant feeding he would exclaim: 'It's not the food that's wrong, it's the baby. Even the Archangel Gabriel couldn't find a suitable diet for this baby.'

Bernard Schlesinger says that whenever a squealing, kicking baby exhibiting all sorts of habit spasms came into the out-patient department at Great Ormond Street, Robert would ask: "What is the treatment here ?' When no answer was forthcoming, he would say: 'Gentlemen, it is a clear cut case of bromide for the mother.'

Dick Bomford was present at a Saturday morning lecture in the old anatomical theatre at the London when the following incident occurred. Many men were about a minute late and the stamping had died down. At five minutes past the hour, three Indians came through the door and crept with self-effacing tactics up the aisle. As was the custom, the stamping of the audience increased until the final peak thump when they sat down. Robert took his pince-nez from his nose and looked severe:

' It is written in the Book that the three wise men from the East came to sit at the feet of the Master. It is not recorded that they were late.'

Jack Linnell says that he hated abbreviations. A receiving room officer sent to out-patients a man with granular kidney with a yellow card labelled G.K. 'What is G.K. gentlemen, I ask you ?' A bright student shouted: 'Maybe it's God knows, sir.' 'There are some kinds of knowledge which even R.R.O's should share with the Deity.'

When he was Robert's house physician $\mathbf{R}$. $\mathbf{H}$. Dobbs wrote on a blueboard 'P.U.O.' Robert turned to him: 'P.U.O., S.U.P., R.I.P. Don't do it again, my boy.'

Russell Brain says that Robert used to tell his class that it was a great mistake to send a patient with insomnia to the country, because the cuckoos would keep him awake.

- There are two types of cardiac case, the one that responds to digitalis, the other that does not, and you can't tell the difference until you try.'

When Eric Currant was his house physician, Robert was on one occasion annoyed at being given a whole bundle of clinical laboratory reports. 'These laboratory pundits think of me as a senile, doddering idiot, incapable of making up my mind, followed around the wards by an achondroplasic house physician, microcephalic clerks, and a myxoedematous sister.'
Bobby Hutch wrote to congratulate Russell Brain on his election as President of the Royal College of Physicians. 'Amongst other duties you may be called upon to write my obituary notice.'

We who have enjoyed your teaching and your writings salute you, Sir Robert. We offer you greetings and congratulations on your eightieth birthday, and wish you and Lady Robert continued happiness in the years to come. As an erudite physician, you taught us many things, but also as a philosopher you helped us to discover how all these things were good to know and worthy to be told. We have always deeply admired your scholarly approach, and we regard you as the outstanding figure of contemporary medicine. We are proud to have been your pupils.

At the London, we remember so well how you stood, tall and elegant in your frock coat with one hand on the curtain rail above the patient's bed. At the end of the ward round, when you washed your hands, sister offered you scented soap of a special brand, and woe betide the probationer who should offer you ordinary soap.

At Great Ormond Street, somehow we think of you in summer garb, the grey frock coat and grey topper. The little girl in the first cot offered you a rose which you pinned on your coat. With a 'Thank you, my dear' you smelt the rose, and the ward round began.

You remember, of course, when your wife was about to present you with a fourth child how keen you were it should be a daughter because already you had three sons. You told us how you laid in a bottle of champagne and a bottle of ginger-beer as alternatives to celebrate the occasion. It was a girl; how happily you attacked the champagne.

Sometimes you lashed us with the irony of your clever tongue, but always you inspired us. And now with students and patients of our own, alike in the lecture room and in the sick room, your example is a constant help to us. Though naturally wishing we could have been more apt pupils, we shall continue to instruct the young in the broad common sense methods for which you became famous.

- And we all praise famous menAncients of the College;

For they taught us common sense-

Tried to teach us common sense-

Truth and God's Own Common Sense,

Which is more than knowledge !'

- Bless and praise we famous men-

Men of little showing -

For their work continueth,

And their work continueth,

Broad and deep continueth,

Great beyond their knowing !' 